\title{
The Influences and Dilemmas of the National Equities Exchange \& Quotations
}

\author{
Jianfeng Jiang \\ Institute of Industrial Economics, Jinan University, Guangzhou, China \\ Email: 1101140858@qq.com
}

Received 9 March 2016; accepted 10 April 2016; published 13 April 2016

Copyright (C) 2016 by author and Scientific Research Publishing Inc.

This work is licensed under the Creative Commons Attribution International License (CC BY). http://creativecommons.org/licenses/by/4.0/

(c) $\underset{\mathrm{EY}}{\mathrm{B}}$ Open Access

\begin{abstract}
As an essential part of the multilayer capital market in China, the detrusion of the NEEQ (National Equities Exchange and Quotations) influences many aspects. Industry structure, market efficiency, fortune allocation will all be promoted to be more reasonable. Certainly, it still leaves much to be undesired, such as deficiency of liquidity, outrageous valuation. However, as related systems implemented gradually, the market could get rid of the trouble.
\end{abstract}

\section{Keywords}

NEEQ, Influence, Dilemma, Market System

\section{Introduction}

The original basis of the NEEQ was firstly started to accept companies retreated from the Main Board in 2003. But unexpectedly, it was not popular with investors, making this board almost virtual. However, under the background of Chinese economy transformation and upgrading, a lot of high-tech companies were newly started which need financial support. The government decided to redefine this board to serve the new high-tech companies in 2009 [1]. As it was born, more and more companies began to take it as a chance to promote their development [2]. To some extent, the NEEQ plays a more important role than the main board referring to the national transformation [3]. Meanwhile, to confirm that the market operates smoothly and permanently, a more complete system should be implemented in the future [4].

\section{Influences of the NEEQ}

\subsection{The NEEQ Has Integrated the Structure of Capital Market}

The NEEQ was started to promote the development of high-tech companies in start-up period. Before the NEEQ 
had been launched, only companies in mature stage are permitted to direct finance in the Chinese capital market while now early-stage companies could also direct finance by issuing their shares in the NEEQ. As this is relative to the national economy transformation and upgrading, the government attaches great importance to it. Until the end of 2015, more than 5000 companies have listed on the NEEQ, direct finance up to 121.6 billion RMB versus the GEM (Growth Enterprise Market) 115.6 billion RMB.

\subsection{Market Efficiency Improvement}

As a public platform built for both early-stage companies and capital, the NEEQ not only improve the finance conditions but also optimize the allocation and efficiency of social capital. Without the NEEQ, capital partners usually searched target one by one with low efficiency, information asymmetry and high cost of exchange. All of this made it difficult to realise capital optimum allocation. And now, with the NEEQ, capital partners could search targeted companies in a public market and command deep research with the target. Besides, participants could complete their transaction within a mechanism system, legal rights and obligations are regulated by relative laws [5]. Thus, the operation efficiency and resource allocation efficiency are both being improved.

\subsection{Promotion of Industry Transformation and Upgrading}

Popular listed companies on the NEEQ could gain very exciting capital premium. Thus, with enormous effect of fortune, people are motivated to provide consumers better services and products. Entrants tend to take industries such as information, medical treatment and new energy as priorities and take research \& innovation as of great importance. There's no doubt that these industries will play key roles in social life and the industry structure will eventually be updated.

\subsection{More Fortune Will Be Gained from the Marketization}

In the past years, market was deeply restricted by political system. Political commands and resources hold the main voice of the market and are regarded as effective means to grab profits. Creative ideas had not been motivated. And now, as the government is gradually cutting the control of the market, people correspondingly are more reluctant to put their intelligence and resources into market innovation to get fortune. And the detrusion of the NEEQ makes this dream easier to come true.

Entrepreneurs could deal their shares with other investors in the NEEQ to get rich in advance as long as their companies are popular with the market. In other words, if you create valuable products or services for consumers, investors will prepay you the bill. So this is a creator age.

As the idea that equity creates fortune, more and more citizens will hold equities. This is because for one thing, more and more companies tend to regard stock incentive as an effective mean to drive the employees to work harder, for the other thing, citizens will be accustomed to increasing their fortune by investing in the equities of good companies.

\section{Analysis about the Dilemmas in the NEEQ}

Listed companies on the NEEQ could profit from multiple aspects. Besides the promotion of comprehensive financing, the increase of in fluency of the stock, the completion of management organisition, the popularity of brand. The conditions to list on the NEEQ are much looser than to list on the Main Board. It mainly has four conditions. The first one: established legally and operated for at least 2 years. The second one: main business is clear and is able to run continuously. The third one: equity structure is clear. The fourth one: under continuous supervision of the host broker.

Based on the realistic conditions, a lot of companies have been attracted to list on the NEEQ. And some of them indeed have reached their goals, such as HengDaTaoBao 8700 million RMB, JiuDing Group almost 10 billion RMB. However, not all the companies listed on the NEEQ are so lucky. More than 1000 companies have no deal since the IPO (Initial Public Offering), which reflects the dilemmas that the NEEQ faced with: inadequate liquidity, outrageous valuation, system deficiency.

\subsection{Limited Function of Finance, Inadequate Liquidity}

Firstly, as the NEEQ was promoted to play a strategic role just for several years, it is inevitable that some kinds 
of dilemmas exist during the development process. For example, due to the stratification and board transition mechanism are still under research and formulation, the investors tend to act prudently for fear of the uncertainty of policies. Secondly, because of the loose conditions to list on the NEEQ, it is indeed normal that some featureless companies failed to gain the eyes of investors. Thirdly, as most of the companies are in early stage, they contain of more potential operation risks which could make the company bankrupt. As a result, investors need to take a relatively longer time to invest the facts. And once they decide to invest resources into the target, they usually tend to hold the stocks for several years. Last but not least, in view of the higher risk in the NEEQ, regulators have set a relatively high standard for investors to enter. At present, only qualified institutional investors and HNWI (High Net Worth Individuals) are permitted to enter the market. Thus, the amount of fund in the NEEQ is correspondingly limited.

\subsection{Outrageous Valuation}

The mean PE (price earning) ratio of the listed companies in the NEEQ is 40 times, and 44 times for dealership companies. In addition to inadequate liquidity, the market-maker system has not worked well. Faced with crowds of companies who need make-market services, market makers tend to collect stocks at a low price for arbitrage rather than improve the market liquidity. With more institutes permitted to carry out this business and experiences spread throughout the market, the market-maker system could work more effectively. Then, market prices could return to a normal level.

\subsection{System Deficiency}

Since the NEEQ was born, it is often regarded by people as a shortcut to list on the Main Board. By listing on the NEEQ in advance could shorten the queue time when they list on the Main Board. But to the NEEQ, attracting more good companies to stay here for long-term running is absolutely necessary to go prosperity. At the same time, the competition among exchanges is more fierce which include the coming of registered system and the creation of a Strategic Emerging Industries Board. So the NEEQ will take measures actively to provide services no poor than the Main Board. Especially when regional supervisions are in place, the propulsion of related systems such as the introduction of public funds, bringing down the threshold of IPO and making market, will be accelerated. For the risks such as malicious fraud, inside manipulation will all be under control [6].

\section{Conclusion}

From the active effects that the NEEQ brings to the society, we can believe that it will be definitely supported by the participants as well as the government. With the development of the market and the detrusion of related system, dilemmas like inadequate liquidity and outrageous valuation will be solved smoothly.

\section{References}

[1] Liu, G.C. (2010) Hit the NEEQ. CITIC Press, Beijing.

[2] Zhang, Y. (2015) The Cost and Advantages for Companies to List on the NEEQ. The Reform and Management, 8, 3740.

[3] He, X.S. (2013) Capital Market Promote the Development of Strategic Industries. Journal of Social Science, 6, 51-55.

[4] Hu, S.L. (2010) Discussions about the Functions, Subject Location and System Innovation. Journal of Economic Research, 10, 23-24.

[5] Li, L.J. (2015) The Poem and Future of the NEEQ. http://jrz.cnstock.com/gdft/201511/3620471.htm

[6] Lin, A.J. (2014) The Development Mode and Strategy of the NEEQ. Reform of Economic System, 5, 111-113. 